\title{
Developing Caenorhabditis elegans neurons may contain both cell-death protective and killer activities
}

\author{
Shai Shaham and H. Robert Horvitz \\ Howard Hughes Medical Institute, Department of Biology, Massachusetts Institute of Technology, Cambridge, \\ Massachusetts 02139 USA
}

\begin{abstract}
We developed a method for examining the effects of overexpressing cell-death-related genes in specific Caenorhabditis elegans neurons that normally live. Using this method, we demonstrated that the cell-death genes ced-3, ced-4, and ced-9 all can act cell autonomously to control programmed cell death. Our observations indicate further that not only the protective activity of ced-9 but also the killer activities of ced-3 and ced-4 are likely to be present in cells that normally live. We propose that both in $C$. elegans and in other organisms a competition between antagonistic protective and killer activities determines whether specific cells will live or die. Our results suggest a genetic pathway for programmed cell death in $C$. elegans in which ced-4 acts upstream of or in parallel to ced-3 and ced-9 negatively regulates the activity of ced-4.
\end{abstract}

[Key Words: C. elegans; programmed cell death; cysteine protease; bcl-2 family; ICE family]

Received December 5, 1995; revised version accepted January 23, 1996.

Programmed cell death is a major and apparently universal aspect of metazoan development and tissue homeostasis (Glücksmann 1950; Ellis et al. 1991a). Programmed cell death serves several functions, including the regulation of cell number, the removal of deleterious cells, and the shaping of tissues and organs. Although a diversity of signals can cause different cells to undergo programmed cell death (e.g., Barres et al. 1993; Vaux 19931, the morphology and kinetics of programmed cell deaths are in many cases highly similar (Stanisic et al. 1978; Cohen and Duke 1984; Martin et al. 1988; Arends and Wyllie 1991), suggesting that the mechanisms responsible for the programmed deaths of different cell types and of cells in different organisms could well be the same.

During the development of the nematode Caenorhabditis elegans, 131 of the 1090 somatic cells generated undergo programmed cell death (Sulston and Horvitz 1977; Kimble and Hirsh 1979; Sulston et al. 1983). Thirteen genes that affect various aspects of the process of programmed cell death in C. elegans have been identified (Hedgecock et al. 1983; Ellis and Horvitz 1986; Ellis and Horvitz 1991; Ellis et al. 1991b; Hengartner et al. 1992; for review, see Horvitz et al. 1994). Three of these genes control the onset of the death process, six act in the phagocytosis of dying cells by their neighbors, and one functions in the digestion of the DNA of cell corpses. Three additional genes affect the fate of programmed cell death of a few specific cells that die during development.

Of the three C. elegans genes that control the onset of programmed cell death, two-ced-3 and ced-4 (ced, cell death abnormal)-are required for programmed cell death to occur: Loss-of-function mutations in either of these genes cause all 131 cells that normally die instead to survive (Ellis and Horvitz 1986). In contrast, the third gene-ced-9-is needed to protect cells that normally survive from undergoing programmed cell death: Lossof-function mutations in ced-9 cause cells that normally live instead to undergo programmed cell death (Hengartner et al. 1992). The extra cell deaths that occur in ced-9 loss-of-function mutants require the activities of ced-3 and ced-4, indicating that ced-9 acts by preventing ced-3 and ced-4 from causing cell death.

Both ced-9 and ced-3 have known mammalian counterparts that function in cell death. ced-9 encodes a protein similar in sequence to the human proto-oncoprotein Bcl-2 (Hengartner and Horvitz 1994a), which like the CED-9 protein can protect cells from programmed cell death (Vaux et al. 1988; Nunez et al. 1990; Hockenbery et al. 1991; Garcia et al. 1992; Sentman et al. 1992; Strasser et al. 1992; for review, see Williams and Smith 1993). Human bcl-2 expressed in transgenic C. elegans can protect nematode cells from undergoing programmed cell death (Vaux et al. 1992; Hengartner and Horvitz 1994a). Human bcl-2 also can rescue nematode cells that die as a consequence of a ced-9 loss-of-function mutation, suggesting that $b c l-2$ might substitute functionally for ced-9 (Hengartner and Horvitz 1994a). Thus, ced-9 and $b c l-2$ seem to be structurally similar and at least somewhat functionally interchangeable.

ced-3 encodes a protein similar in sequence to mam- 
malian interleukin-1 $\beta$ (IL-1 $\beta$ ) converting enzyme (ICE) (Yuan et al. 1993), a cysteine protease isolated on the basis of its ability to cleave a $31-\mathrm{kD}$ pro-IL- $1 \beta$ protein to generate the $17.5-\mathrm{kD}$ mature cytokine (Cerretti et al. 1992; Thornberry et al. 1992). Overexpression of either CED-3 protein or ICE can cause rat fibroblasts to undergo programmed cell death (Miura et al. 1993). Furthermore, the programmed cell death induced when chick dorsal-root ganglion neurons are deprived of nerve growth factor can be inhibited by expression of the cowpox virus protein crmA (Gagliardini et al. 1994), an inhibitor of ICE (Ray et al. 1992), and mice harboring a disruption of the ICE gene are defective in Fas-mediated apoptosis (Kuida et al. 1995). These observations indicate that cysteine proteases of the CED-3/ICE family can cause mammalian cells to undergo programmed cell death and suggest that such proteases act endogenously in the programmed deaths that follow growth factor deprivation and Fas induction.

Both CED-3 and ICE are similar in sequence to the proteins encoded by the mouse nedd-2 gene and its human homolog Ich-1, which can cause cell death when overexpressed in either mouse fibroblasts or neuroblastoma cells (Kumar et al. 1994; Wang et al. 1994), and to the product of the human gene CPP32, which can cause cell death when overexpressed in insect Sf9 cells (Fernandes-Alnemri et al. 1994). In addition, bcl-2 can inhibit the cell deaths caused by the expression of the CED-3, ICE (Miura et al. 1993), or NEDD-2/ICH-1 proteins (Kumar et al. 1994; Wang et al. 1994) or by the deprivation of nerve growth factor (Gagliardini et al. 1994), suggesting that just as ced-3 function is inhibited by ced-9, the action of ICE-like cysteine proteases can be inhibited by $b c l-2$.

Because mutations in either ced-3 or ced-4 block all naturally occurring programmed cell deaths in C. elegans (Ellis and Horvitz 1986), both of these genes normally must be functional for the proper execution of programmed cell death. However, this observation does not reveal whether the expression of these genes is restricted to cells that die or whether overexpression of one or both of these genes would suffice to cause a cell that would otherwise survive instead to undergo programmed cell death. To address these issues, we performed the experiments described below.

\section{Results \\ Overexpression of either ced-3 or ced-4 can kill cells that normally live}

To test whether expression of ced-3 or ced-4 is sufficient to kill cells that normally live, we placed cDNAs for each of these genes under the control of the promoter for the C. elegans gene mec-7, which is expressed in the six touch neurons (ALML, ALMR, AVM, PVM, PLML, and PLMR) and in a few other cells (Savage et al. 1989; M. Chalfie, pers. comm.). The $\mathrm{P}_{\text {mec- } 7}$ ced-3 and $\mathrm{P}_{\text {mec- }-7}$ ced-4 fusion constructs were injected separately into wild-type animals, and independent lines of worms homozygous for integrated copies of the constructs were established. We obtained three lines $\left(\mathrm{P}_{\text {mec- }-7}\right.$ ced-3A, $\mathrm{P}_{\text {mec- }-7}$ ced-3B, and $\mathrm{P}_{\text {mec }-7}$ ced $-3 C$ ) homozygous for integrated copies of $\mathrm{P}_{\text {mec- }-7}$ ced -3 and four lines $\left(\mathrm{P}_{\text {mec- }-7}\right.$ ced-4A, $\mathrm{P}_{\text {mec }-7}$ ced- $4 \mathrm{~B}$, $\mathrm{P}_{\text {mec }-7}$ ced-4C, and $\mathrm{P}_{\text {mec- } 7}$ ced-4D) homozygous for integrated copies of $\mathrm{P}_{\text {mec } \rightarrow}$ ced-4.

To determine whether cells that normally express mec-7 were absent in animals carrying the $\mathrm{P}_{\text {mec- }-7}$ ced-3 or $\mathrm{P}_{\text {mec- } 7}$ ced-4 transgenes, we scored animals for the presence or absence of the two ALM neurons. We scored the left side of the animal for the presence of the ALML neuron and the right side for the presence of the ALMR neuron. As shown in Table 1, we observed that ALM cells were missing in some of the lines we obtained. For example, ALMs were present on only 9 of the $46(20 \%)$ sides scored in line $\mathrm{P}_{\text {mec- }}$ ced-3A and on only 4 of the 39 $(10 \%)$ sides scored in line $\mathrm{P}_{\text {mec. } 7}$ ced-4A. We also injected $\mathrm{P}_{\text {mec- } 7}$ ced-3 and $\mathrm{P}_{\text {mec- }-7}$ ced-4 constructs together and established two lines containing integrated arrays harboring both constructs (lines $\mathrm{P}_{\text {mec. }}$ ced-3/4A and $\mathrm{P}_{\text {mec- } 7}$ ced$3 / 4 \mathrm{~B}$. Wild-type animals carrying these arrays showed a slight loss of ALM neurons: ALMs were present on 35 of the $37(95 \%)$ and 45 of the $46(98 \%)$ sides scored, respectively. Wild-type animals not carrying these arrays always contained both ALMs $(n=31)$, and animals expressing a $\mathrm{P}_{\text {mec- } 7}$ lac $Z$ construct (jeIs1; J. Way, pers. comm.) had ALMs on 40 of the $40(100 \%)$ sides scored, suggesting that the presence of an array or the expression of any protcin will not kill these cells (also, see below). These results suggest that overexpression of either ced-3 or ced-4 is sufficient to kill the ALMs in wild-type animals and that both ced-3 and ced-4 can kill cells in a cellautonomous fashion. To confirm that the $\mathrm{P}_{\text {mec- } 7}$ ced -4

Table 1. Overexpression of ced-3 or ced-4 can kill the ALM neurons

\begin{tabular}{|c|c|}
\hline \multicolumn{2}{|c|}{$\begin{array}{c}\begin{array}{c}\text { Percent surviving ALMs } \\
\text { (no. ALMS/no. sides scored) }\end{array} \\
\end{array}$} \\
\hline & \\
\hline- & $100(31 / 31)$ \\
\hline $\mathrm{P}_{\text {mec-7 } 7} l a c Z$ & $100(40 / 40)$ \\
\hline $\mathrm{P}_{m e c-7} c e d-3 \mathrm{~A}$ & $20(9 / 46)$ \\
\hline $\mathrm{P}_{\text {mec-7 }}$ ced-3B & $42(16 / 38)$ \\
\hline $\mathrm{P}_{\text {mec- } 7}$ ced-3C & $100(48 / 48)$ \\
\hline $\mathrm{P}_{\text {mec- } 7}$ ced-4A & $10(4 / 39)$ \\
\hline $\mathrm{P}_{\text {mec } .7}$ ced-4B & $87(33 / 38)$ \\
\hline $\mathrm{P}_{\text {mec }-7}$ ced-4C & $98(39 / 40)$ \\
\hline $\mathrm{P}_{\text {mec-7 }}$ ced-4D & $98(40 / 41)$ \\
\hline $\mathrm{P}_{\text {mec }-7}$ ced-3/4A & $95(35 / 37)$ \\
\hline $\mathrm{P}_{\text {mec-7 } 7}$ ced-3/4B & $98(45 / 46)$ \\
\hline
\end{tabular}

Each row represents an independently derived line of C. elegans homozygous for a given integrated transgene or pair of transgenes. Fractions indicate the number of ALMs per number of animal sides scored. For each line named $\mathrm{P}_{\text {mec- }-}$ ced- $n X, n$ is either 3 or 4 (for ced-3 or ced-4) and $X$ identifies the specific independent line; in rows 10 and $11, n$ is $3 / 4$, indicating the presence of both ced-3 and ced-4 transgenes in each of the two independently derived worm lines. 
constructs expressed CED-4 protein, we examined surviving ALMs in $\mathrm{P}_{\text {mec- } 7}$ ced-4-containing lines in a wildtype background for reactivity to anti-CED-4 polyclonal antibodies. ALMs in line $\mathrm{P}_{\text {mec }-7}$ ced-4A stained more strongly than did ALMs in the other three insertion lines (data not shown), consistent with the observation that ALMs died more frequently in this line. Because no antiCED-3 antibody was available, we could not directly assess the levels of CED-3 expression in $\mathrm{P}_{\text {mec-7 }}$ ced-3-containing lines.

\section{Endogenous ced-9 activity protects against killing by overexpressed ced-3 or ced- 4}

Although, as described above, overexpression of either ced -3 or ced -4 caused the deaths of ALM neurons, many ALMs survived in animals transgenic for these cell-death genes. Because the gene ced-9 can protect cells against cell death mediated by ced -3 and $c e d-4$, it seemed plausible that eliminating endogenous ced-9 function would result in enhanced killing by a ced-3 or ced-4 transgene. To test this hypothesis, we introduced our ced-3 and ced-4 transgene constructs into ced-9(1f); ced-3 or ced-4 ced-9 (lf) animals. [ced-9(lf) single-mutant animals die, making it impossible to overexpress ced-3 or ced-4 in such a strain, but ced-9(1f); ced-3 and ced-4 ced-9(lf) double-mutant animals are viable (Hengartner et al. 1992)].

As shown in Table $2 \mathrm{~A}$, lines containing a $\mathrm{P}_{\text {mec- } 7}$ ced-3 transgene and the chromosomal mutation ced-9(n2812)

Table 2. Effects of ced-9 on killing by ced-3 or ced-4 overexpression

\begin{tabular}{|c|c|c|}
\hline & \multicolumn{2}{|c|}{$\begin{array}{l}\text { Percent surviving ALMs } \\
\text { (no. ALMs/no. sides scored) }\end{array}$} \\
\hline & ced-9; ced-3 & ced -3 \\
\hline \multicolumn{3}{|c|}{$\begin{array}{c}\text { A. ALM killing by ced-3 overexpression is better } \\
\text { in a ced-9(lf) background }\end{array}$} \\
\hline $\mathrm{P}_{m e c-7}$ ced-3A & $0(0 / 29)$ & $47(16 / 34)$ \\
\hline $\mathrm{P}_{\text {mec }-7}$ ced-3B & $0(0 / 37)$ & $30(8 / 27)$ \\
\hline $\mathrm{P}_{\text {mec }-7}$ ced-3C & $21(9 / 43)$ & $100(34 / 34)$ \\
\hline $\mathrm{P}_{\text {mec-7 }}$ ced-3/4A & $43(16 / 37)$ & $100(40 / 40)$ \\
\hline \multirow[t]{2}{*}{$\mathrm{P}_{m e c-7} c e d-3 / 4 \mathrm{~B}$} & $67(18 / 27)$ & $100(46 / 46)$ \\
\hline & ced-4; ced-9 & ced-4 \\
\hline
\end{tabular}

B. ALM killing by ced-4 overexpression is better in a ced-9(lf) background ${ }^{\mathrm{b}}$

\begin{tabular}{|c|c|c|}
\hline $\mathrm{P}_{\text {mec }-7}$ ced-4A & $0(0 / 30)$ & $43(12 / 28)$ \\
\hline $\mathrm{P}_{\text {mec }-7}$ ced-4B & $53(18 / 34)$ & $94(32 / 34)$ \\
\hline $\mathrm{P}_{\mathrm{mec}-7} c e d-4 \mathrm{C}$ & $42(15 / 36)$ & $97(36 / 37)$ \\
\hline $\mathrm{P}_{\text {mec-7 }}$ ced-4D & $15(4 / 27)$ & $100(36 / 36)$ \\
\hline $\mathbf{P}_{\text {mec-7 }}$ ced-3/4A & $70(35 / 50)$ & $100(41 / 41)$ \\
\hline $\mathbf{P}_{m e c-7}$ ced-3/4B & $74(37 / 50)$ & $100(30 / 30)$ \\
\hline
\end{tabular}

${ }^{\text {a The column headings identify the chromosomal genotypes of }}$ the strains examined. The alleles used were ced-9(n2812) and ced-3(n717), except for the experiment involving $\mathrm{P}_{\text {mec. }}$ ced-3A, in which ced-3(n3002) was used.

${ }^{b}$ The column headings identify the chromosomal genotypes of the strains examined. The alleles used were ced-9(n2812) and ced-4(n1162). had fewer ALMs than did lines containing the corresponding transgene in the presence of the wild-type ced-9 gene. For example, for the $\mathrm{P}_{\text {mec- }}$ ced-3A transgene, ALMs were present on 0 of the $29(0 \%)$ sides scored in a ced-9; ced-3 background yet were present on 16 of the 34 $(47 \%)$ sides scored in a ced-3 background. Similarly, lines containing a $\mathrm{P}_{\text {mec- } 7}$ ced-4 transgene and the chromosomal mutation ced-9(n2812) had fewer ALMs than did lines containing the corresponding transgene in the presence of the wild-type ced-9 gene (Table $2 \mathrm{~B}$ ). For the $\mathrm{P}_{\text {mec-7 }}$ ced-4A transgene, ALMs were present on 0 of the $30(0 \%)$ sides scored in a ced-4 ced-9 background yet were present on 12 of the $28(43 \%)$ sides scored in a ced-4 background. Lines containing integrated copies of both a ced-3 and a ced-4 transgene also showed fewer ALMs surviving in a ced-9(n2812) background (Tables $2 A, B)$. In line $\mathrm{P}_{\text {mec- } 7}$ ced-3/4A, for example, ALMs were present on only 16 of the $37(43 \%)$ sides scored in a ced-9; ced-3 genetic background but were present on 40 of the 40 $(100 \%)$ sides scored in a ced-3 background alone (Table 2A). We suspect that the double transgenes were not expressed at levels as high as the single transgenes /see below), which might explain why killing in these lines was reduced in comparison to killing in some of the lines with single transgenes. These results suggest that killing by overexpression of either ced-3 or ced-4 is more efficient in the absence of ced-9 function and are consistent with the hypothesis that ced-9 acts to regulate negatively the activities of both ced-3 and ced-4 (Hengartner et al. 1992; see Discussion). Furthermore, because ced-9 acts cell autonomously to inhibit cell death (see below), these results suggest that ced-9 is normally expressed in the ALM neurons (also, see Discussion).

We also tested the effect of the ced-9 partial loss-offunction allele $n 1950$ n2161 on ALM cell death in strains containing the $\mathrm{P}_{\text {mec-7 }}$ ced-3A transgene and again observed enhanced killing: ALMs were present on 1 of the $15(7 \%)$ sides scored in an unc-69(e587) ced-9(n1950 n2161) background. These results suggest that it is a reduction of ced-9 activity that allows more efficient killing rather than a specific action of the ced-9(n2812) allele.

The ced-9 gain-of-function allele $n 1950$ is a missense mutation that acts oppositely to ced-9(1f) alleles and prevents the normal cell deaths that occur during $C$. elegans development (Hengartner et al. 1992; Hengartner and Horvitz 1994b). We tested the ability of ced-9(n1950) to prevent the deaths of ALM neurons in animals carrying $\mathrm{P}_{\text {mec-7 }}$ ced-3 or $\mathrm{P}_{\text {mec-7 }}$ ced-4 transgenes. As shown in $\mathrm{Ta}-$ ble 3 , the $n 1950$ mutation did not consistently alter the abilities of these transgenes to cause ALM death.

\section{Overexpression of ced-3 or ced-4 causes programmed cell death}

The experiments described above indicated that overexpression of either ced-3 or ced-4 can lead to an absence of ALM neurons. To determine whether mec-7-expressing neurons were missing because they underwent programmed cell death, we observed directly the cell divi- 
Table 3. ced-9(n1950) does not decrease ALM killing by overexpression of ced- 3 or ced- 4

\begin{tabular}{lcr}
\hline & \multicolumn{2}{c}{$\begin{array}{c}\text { Percent surviving ALMs } \\
\text { (no. ALMs/no. sides scored) }\end{array}$} \\
\cline { 2 - 3 } & wild type & ced-9(n1950) \\
\hline $\mathrm{P}_{\text {mec-7}}$ ced-3A & $20(9 / 46)$ & $58(18 / 31)$ \\
$\mathrm{P}_{\text {mec-7 }}$ ced-3B & $42(16 / 38)$ & $27(10 / 37)$ \\
$\mathrm{P}_{\text {mec-7 }}$ ced-3C & $100(48 / 48)$ & $100(42 / 42)$ \\
$\mathrm{P}_{\text {mec-7}}$ ced-4A & $10(4 / 39)$ & $4(2 / 47)$ \\
$\mathrm{P}_{\text {mec-7 }}$ ced-4B & $87(33 / 38)$ & $95(39 / 41)$ \\
$\mathrm{P}_{\text {mec-7 }}$ ced-4C & $98(39 / 40)$ & $100(41 / 41)$ \\
$\mathrm{P}_{\text {mec } 7}$ ced-4D & $98(40 / 41)$ & $100(42 / 42)$ \\
$\mathrm{P}_{\text {med-7 }}$ ced-3/4A & $97(36 / 37)$ & $100(46 / 46)$ \\
$\mathrm{P}_{\text {mec-7 }}$ ced-3/4B & $98(45 / 46)$ & $97(34 / 35)$ \\
\hline
\end{tabular}

The column headings identify the chromosomal genotypes of the strains examined.

sions leading to the formation of the mec-7-expressing neuron PVM (Chalfie 1993) in animals carrying trans- genes $\mathrm{P}_{\text {mec- } 7}$ ced-3A, $\mathrm{P}_{\text {mec-7 }}$ ced-3C, or $\mathrm{P}_{\text {mec- } 7}$ ced-3/4A in a ced-9(n2812); ced-3(n717) background or transgene $\mathrm{P}_{\text {mec-7 }}$ ced-4A in a ced-4(n1162) ced-9(n2812) background. These divisions occur postembryonically and are thus easier to follow than the divisions leading to the formation of the ALMs. As illustrated in Figure 1A, presumptive PVM neurons in these lines showed the characteristic refractile appearance of programmed cell deaths viewed using Nomarski optics (17 animals and 12 deaths observed). These deaths were morphologically indistinguishable from normal programmed cell deaths.

We also analyzed the ultrastructure of a cell corpse resulting from a PVM cell death. Figure $1 \mathrm{C}$ shows a PVM cell that died and was engulfed by a neighboring cell. The darkly staining cytoplasm and nucleus, the small cytoplasmic volume, and the darkly staining matter within the nucleus are all characteristic features of C. elegans cells that normally die by programmed cell death (Robertson and Thomson 1982; Ellis et al. 1991b), suggesting that the deaths we observed were ultrastructurally similar to normal programmed cell deaths.

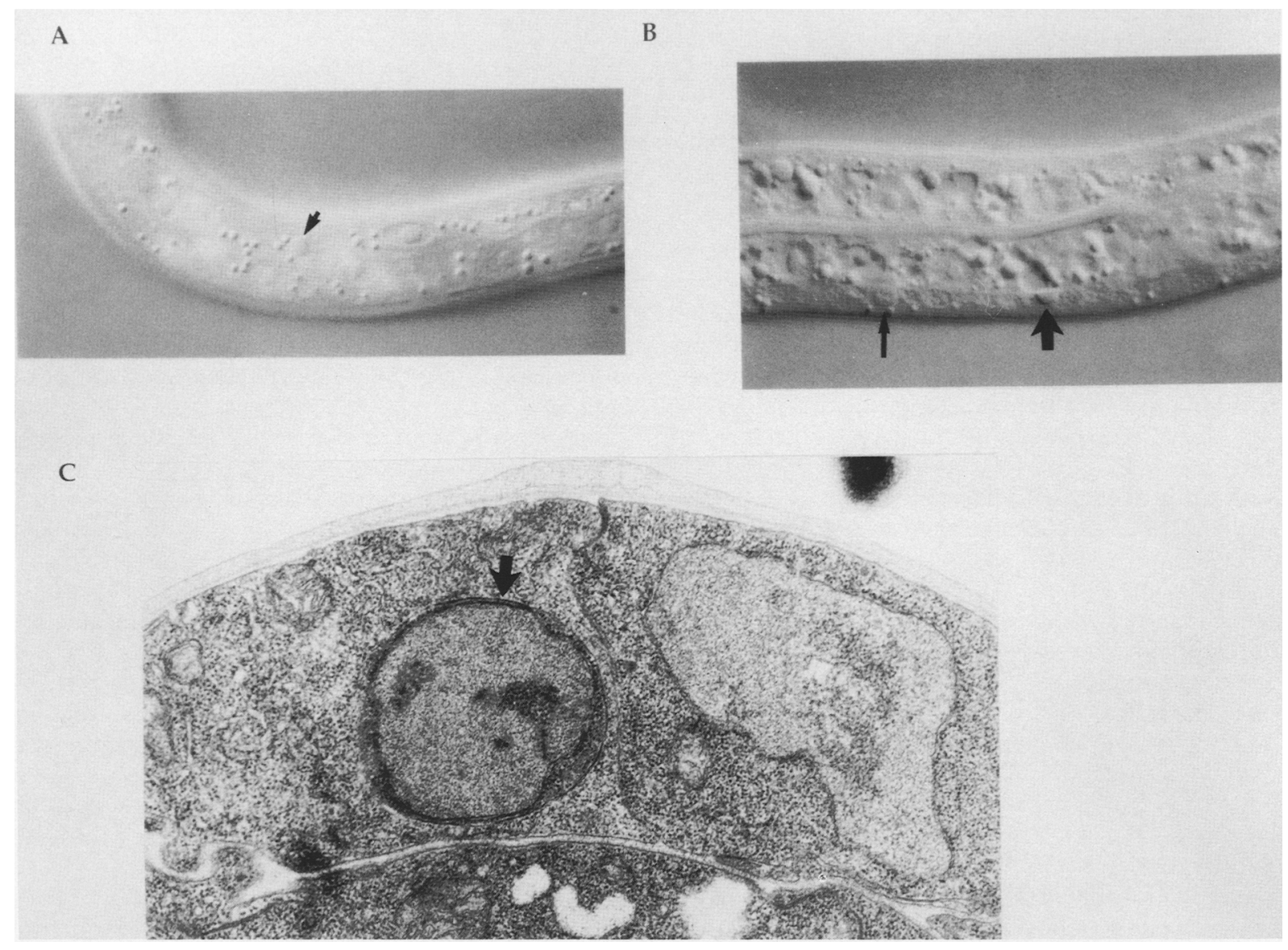

Figure 1. Cell death induced by overexpression of ced-3 and ced-4 resembles normal programmed cell death. $(A \mid$ Nomarski photomicrograph of a dying PVM cell (arrow) in a ced-9(n2812); ced-3(n717) animal carrying the $\mathrm{P}_{\text {mec- }}$ ced-3/4A transgene (see text for details). Anterior is to the left; dorsal is on top. $(B)$ Nomarski photomicrograph of dying VD5 (small arrow) and VD6 (large arrow) neurons in a ced-9(n2812); ced-3(n717) animal carrying the $\mathrm{P}_{u n c-30}$ ced-3/4 transgene. Anterior is to the left; dorsal is on top. (C) Electron micrograph showing a dying PVM cell (arrow) located dorsolaterally posterior to the primordial gonad in an L1 animal. The cell was engulfed by a neighboring hypodermal cell (see text for details). 
A

ced $-4 \longrightarrow$ ced $-3 \longrightarrow$ death

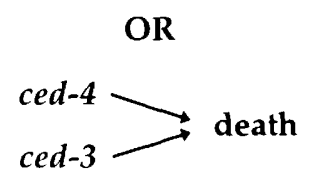

B

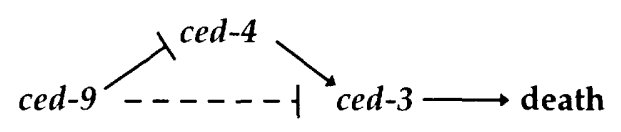

OR

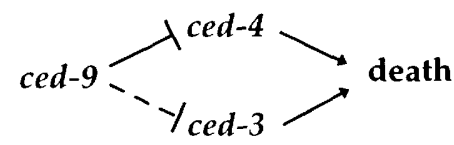

Figure 2. Possible genetic pathways for programmed cell death in C. elegans. Pointed arrows indicate positive regulation; blunt arrows indicate negative regulation. $(A)$ ced-4 either activates ced-3 (top) or acts together with ced-3 (bottom) to induce programmed cell death. $(B)$ ced -9 prevents cell killing by ced -3 by acting at least in part via ced-4. We have no evidence for or against the hypothesis that ced-9 also acts independently of ced-4 to inhibit ced-3-mediated cell killing. This potential interaction is depicted with a broken line. See text for details.

To establish further that the deaths caused by overexpression of ced-3 or ced-4 were similar to programmed cell deaths, we examined first larval stage (L1) ced1(e1735); ced-4(n1162) ced-9(n2812) animals containing the $\mathrm{P}_{\text {mec- }}$ ced-4A transgene for the presence of unengulfed ALM corpses. Animals carrying the ced-1(e1735) mutation fail to engulf many of the corpses that result from programmed cell death, causing these corpses to persist for hours or even days (Hedgecock et al. 1983). We observed corpses on 11 out of 40 sides near the BDU cell (the sister cell of the ALM), and we observed corpses in the normal location of the ALM on 2 out of 40 sides, suggesting that the ALMs often, but not always, died before migrating posteriorly. That $27 / 40$ sides scored did not have observable corpses presumably reflects the incomplete penetrance of the ced-1(e1735) mutation (Ellis et al. 1991b). We obtained similar results using the $\mathrm{P}_{\text {mec- } 7}$ ced-3A transgene in a ced-1(e1735); ced-3(n3002) background (data not shown). These findings suggest that the gene ced-1, which is required for the engulfment of corpses generated by normal programmed cell death, is also required for the engulfment of the corpses generated by overexpression of ced-3 or ced-4.

The gene nuc-1 is required for the degradation of DNA of cells that die by programmed cell death (Sulston 1976; Hevelone and Hartman 1988). We examined the left sides of ced-3(n3002); nuc-1(e1392) animals containing the transgene $\mathrm{P}_{\text {mec }-7}$ ced-3A and stained with the DNA stain 4,6-diamidino-2-phenylindole (DAPI). Near the po- sition of the BDU cell, 7 of the 10 sides had DAPI-positive compact structures that did not correspond to visible nuclei when viewed using Nomarski optics and that looked like structures generated by programmed cell death in animals carrying the nuc-1(e1392) mutation. These findings suggest that the gene nuc-1, which is required for the degradation of the DNA of normally dying cells, is also required for the degradation of the DNA of cells dying because of the overexpression of ced-3 or ced-4.

Programmed cell death caused by overexpression of ced-3 or ced- 4 requires functional ced- 3 and ced-4 products

To determine whether expression of a functional ced-3 or ced-4 cDNA was needed to kill cells in the experiments described above, we constructed and analyzed lines containing ced-3 or ced-4 transgenes with missense mutations. Because we did not need to score a given array in a number of different genetic backgrounds, we used extrachromosomal arrays [which are easier to generate than integrated arrays (Fire 1986; Way and Chalfie 1988)] for these experiments. As controls, we used wildtype ced-3 and ced-4 constructs maintained on extrachromosomal arrays. As shown in Table 4A, 100\% of the ALMs survived in ced-9(n2812); ced-3(n717) animals carrying $\mathrm{P}_{\text {mec-7 }}$ ced-3 fusion constructs containing a cysteine-to-alanine substitution at position 358 of the CED-3 protein. This mutation alters a residue that corresponds to a cysteine essential both for the protease activity of ICE (Cerretti et al. 1992; Thornberry et al. 1992) and for the protease activity of CED-3 (Xue and Horvitz 1995; D. Xue, S. Shaham, and H.R. Horvitz, unpubl.). In contrast, only $\sim 50 \%$ of ALMs survived in animals containing the wild-type constructs. This result suggests that active CED- 3 is needed for ALM cell death and supports the notion that CED-3 is a cysteine protease.

Similarly, $100 \%$ of the ALMs survived in ced-4(n1162) ced-9(n2812) animals carrying $\mathrm{P}_{\text {mec-7 }}$ ced-4 fusions containing an isoleucine-to-asparagine substitution at position 258 of the CED-4 protein (Table 4B). This mutation introduces a change identical to that found in the mutant ced-4 allele n1948 (Yuan and Horvitz 1992). Only $\sim 50 \%$ of ALMs survived in animals containing the wildtype ced-4 constructs. This result suggests that active CED-4 is needed for ALM killing and confirms that the change observed in n1948 animals is the cause of the Ced-4 mutant phenotype. Thus, killing by overexpression of ced-3 or ced-4 requires transgenes that encode functional CED-3 or CED-4 proteins.

To determine whether the deaths of the ALM neurons were induced specifically by overexpression of the cell death proteins CED-3 and CED-4, we tested constructs that should have overexpressed other proteins (Escherichia coli $\beta$-galactosidase, murine ICE, and C. elegans NCC-1) under the control of the mec-7 promoter. The presence of these constructs in ced-9; ced-3 or ced-4 ced-9 worms did not cause ALM cell death (data not 
Table 4. Mutant CED-3 or CED-4 proteins fail to kill ALM neurons

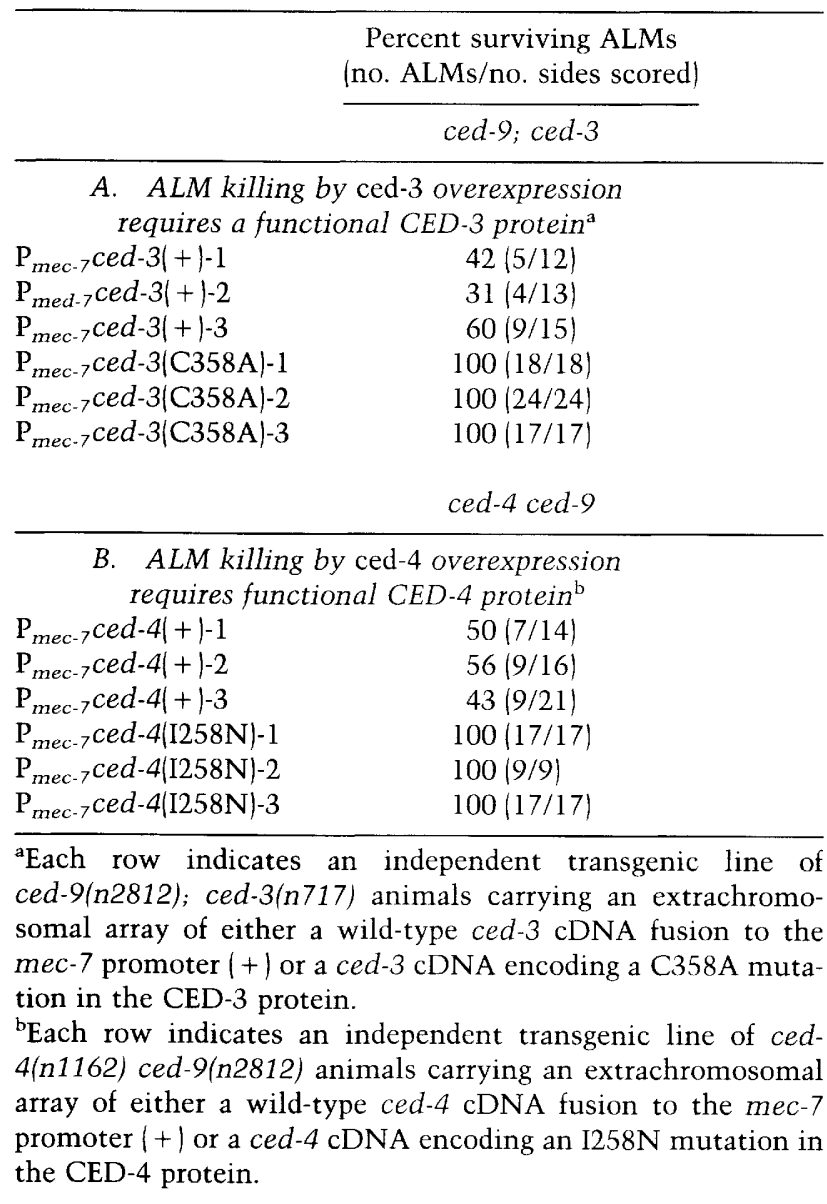

shown), suggesting that it is not simply excess or foreign protein that killed the ALMs in the experiments described above.

Efficient ectopic killing by overexpression of ced-4 requires ced-3 activity

To examine the requirement for endogenous ced-3 in the killing of ALMs by $\mathrm{P}_{\text {mec-7 }}$ ced-4 transgenes, we introduced these transgenes into ced-3 mutant strains. Table 5 shows that killing of ALMs in all four $\mathrm{P}_{\text {mec- } 7}$ ced-4 insertion lines was strongly inhibited by reduction-of- function mutations in the endogenous ced-3 gene by comparison with the level of killing in a wild-type ced-3 background. For example, in line $\mathrm{P}_{\text {mec-7 }}$ ced-4A, ALMs survived on 4 of the $39(10 \%)$ sides scored in a wildtype background but survived on 27 of the $38(71 \%)$ sides scored in a ced-3 background. Similarly, in line $\mathrm{P}_{\text {mec-7 }}$ ced-4A, ALMs survived on 0 of the $30(0 \%)$ sides scored in a ced-4 ced-9 background but survived on 27 of the $38(71 \%)$ sides scored in a ced-4 ced-9; ced-3 background. Interestingly, even though reducing ced-9 function enhanced killing of the ALM neurons with respect to a wild-type background in the presence of a wild-type endogenous ced-3 gene lced-4 ced-9 column vs. wildtype column), killing was greatly reduced in a strain containing mutations in both ced-9 and ced-3 (ced-4 ced-9; ced-3 column). These results suggest that killing by $\mathrm{P}_{\text {mec-7 }}$ ced-4 is greatly facilitated by the presence of endogenous ced -3 and that the need for ced -3 function cannot be overcome by eliminating the function of ced-9 using a mutation that is likely to have little if any ced-9 function based on both genetic and molecular criteria (Hengartner and Horvitz 1994a; S. Shaham and H.R. Horvitz, unpubl.).

To determine if the protection against ALM killing by $\mathrm{P}_{\text {mec-7 }}$ ced-4 constructs observed in these experiments was specific to the ced-3 allele $(n 717)$ used, we examined the abilities of other ced-3 alleles to inhibit killing by ced-4 overexpression. As shown in Table 6, all five other ced -3 alleles tested also inhibited killing. Furthermore, the ability of a ced-3 mutation to cause survival of cells that normally die correlated roughly with its ability to prevent killing of ALM neurons by $\mathrm{P}_{\text {mec- } 7}$ ced-4A. Animals carrying the ced-3 allele n1040, for example, contained an average of 7.6 extra cells in the anterior pharynx; these cells would normally have died in wild-type animals. ALMs survived on 35 of the $64(55 \%)$ sides scored in line $\mathrm{P}_{\text {mec-7 }}$ ced-4A containing the $n 1040$ mutation. However, animals harboring the ced-3 allele n2433 contained an average of 12.4 extra cells in the anterior pharynx, and ALMs survived on 33 of the 41 (80\%) sides scored in line $\mathrm{P}_{\text {mec }-7}$ ced-4A containing this mutation. Although $n 2433$ is the most severe ced-3 allele known (S. Shaham and H.R. Horvitz, unpubl.; M. Hengartner, pers. comm.), neither $n 2433$ nor any other ced-3 allele characterized to date is unequivocally a null allele based upon molecular and genetic criteria (Yuan et al. 1993; S.

Table 5. ALM killing by ced-4 overexpression is inhibited by a mutation in the endogenous ced-3 gene

\begin{tabular}{llccc}
\hline & \multicolumn{4}{c}{ Percent surviving ALMs (no. ALMs/no. sides scored) } \\
\cline { 2 - 5 } & wild type & \multicolumn{1}{c}{ ced-3 } & ced-4 ced-9 & ced-4 ced-9; ced-3 \\
\hline $\mathrm{P}_{\text {mec-7 }}$ ced-4A & $10(4 / 39)$ & $71(27 / 38)$ & $0(0 / 30)$ & $71(27 / 38)$ \\
$\mathrm{P}_{\text {mec. } 7 \text { ced-4B }}$ & $87(33 / 38)$ & $100(20 / 20)$ & $53(18 / 34)$ & $84(27 / 32)$ \\
$\mathrm{P}_{\text {mec. } 7 \text { ced-4C }}$ & $98(39 / 40)$ & $100(37 / 37)$ & $42(15 / 36)$ & $98(39 / 40)$ \\
$\mathrm{P}_{\text {mec }-7}$ ced-4D & $98(40 / 41)$ & $100(36 / 36)$ & $15(4 / 27)$ & $100(40 / 40)$ \\
\hline
\end{tabular}

The column headings identify the chromosomal genotypes of the strains examined. The alleles used were ced-9(n2812), ced-3(n717), and ced-4(n1162). 
Table 6. The activity of the endogenous ced-3 allele determines the extent of ALM killing by ced-4 overexpression

\begin{tabular}{llcc}
\hline & \multicolumn{1}{c}{ Molecular defect } & $\begin{array}{c}\text { Number of extra cells } \\
\text { in anterior of pharynx }\end{array}$ & $\begin{array}{c}\text { Percent surviving ALMs } \\
\text { (no. ALMs/no. sides scored) }\end{array}$ \\
\hline Wild type & none & $0.1 \pm 0.4(40)$ & $10(4 / 39)$ \\
ced-3(n1040) & L27F & $7.6 \pm 1.2(11)$ & $55(35 / 64)$ \\
ced-3(n1129) & A449V & $8.7 \pm 1.2(10)$ & $67(20 / 30)$ \\
ced-3(n717) & Exon 7 splice acceptor G to A & $11.2 \pm 2.0(10)$ & $71(27 / 38)$ \\
ced-3(n718) & G65R & $11.8 \pm 1.0(10)$ & $73(47 / 64)$ \\
ced-3(n2433) & G360S & $12.4 \pm 0.9(10)$ & $80(33 / 41)$ \\
\hline
\end{tabular}

Rows indicate the genotype of the strain examined. The average number of extra cells in the anterior region of the pharynx in each mutant \pm S.D. are shown; the number of animals examined is in parentheses. Fractions indicate the number of ALMs per number of sides scored in a $\mathrm{P}_{\text {med-7 }}$ ced-4A background in a given mutant line. The expected number of cell deaths in the anterior pharynx during normal development is 16 .

Shaham ahd H.R. Horvitz, unpubl.). Thus, it is possible that the complete elimination of ced-3 function would totally prevent killing by ectopic ced-4 expression in this line and hence that ALM killing by a ced-4 transgene absolutely requires ced-3 function.

\section{Ectopic killing by overexpression of ced-3 does not require ced-4 function}

Similarly, to examine the requirement for endogenous ced-4 in the killing of ALMs by $\mathrm{P}_{\text {mec- } 7}$ ced-3 transgenes, we introduced these transgenes into ced-4 mutant strains. For these experiments we used the ced-4 allele n1162, which is a nonsense mutation that should result in premature termination of the CED-4 protein at amino acid 79. No detectable ced-4 RNA or protein is produced by this strain (Yuan and Horvitz 1992; S. Shaham and H.R. Horvitz unpubl.), and, thus, this allele is an excellent candidate for being a molecular null allele. Table 7, shows that ALM survival in $\mathrm{P}_{\text {mec- } 7}$ ced-3- containing lines was not consistently greater in a ced-4(n1162) mutant background than in a wild-type background. For example, in line $\mathrm{P}_{\text {mec-7 }}$ ced-3B, ALMs survived on 16 of the $38(42 \%)$ sides scored in a wild-type background and on 18 of the $61(30 \%)$ sides scored in a ced-4(n1162) background. These observations contrast with those presented above, which indicate that ced-3 mutations reduced the killing efficiency of $\mathrm{P}_{m e c-7}$ ced-4 constructs. Together these findings suggest a basic asymmetry between the killing actions of ced-3 and ced-4. Supporting this notion, whereas killing in line $\mathrm{P}_{\text {mec-7 }}$ ced-4A was more efficient in a wild-type background than was kill- ing in line $\mathrm{P}_{m e c-7}$ ced-3A, killing in the former line was much weaker in a ced-4 ced-9; ced-3 background. These observations suggest that killing by a ced-4 construct is more dependent on endogenous ced -3 than is killing by a ced-3 construct dependent on endogenous ced-4 and further support the notion that ced-4 acts upstream of or in parallel to ced-3.

When we compared the extent of ALM survival in $\mathrm{P}_{\text {mec-7 }}$ ced-3-containing lines in a ced-9; ced-3 background with survival in a ced-4 ced-9; ced-3 background, we noticed that the latter background caused reduced killing. As shown in Table 7, fewer ALMs survived in the ced-9; ced-3 background than in the ced-4 ced-9; ced-3 background in all $\mathrm{P}_{\text {mec-7 }}$ ced-3-containing lines. In line $\mathrm{P}_{\text {mec-7 }}$ ced-3B, for example, ALMs survived on 0 of the 37 $10 \%$ ) sides scored in a ced-9; ced-3 background but on 12 of the $32(37 \%)$ sides scored in a ced-4 ced-9; ced-3 background. This result suggests that in the absence of endogenous ced-9, ced-4 promotes killing caused by ced-3 overexpression (see Discussion).

\section{Protection by ced-9 against ced-3-induced killing is reduced by a mutation that decreases ced-4 activity}

As described above, endogenous ced-9 function inhibited killing by overexpression of ced-3 and ced-4. Specifically, ALM survival in $\mathrm{P}_{\text {mec-7 }}$ ced-3 and $\mathrm{P}_{\text {mec-7 }}$ ced-4 lines was greater in ced-9 $|+|$ strains than in strains containing a ced-9 loss-of-function mutation (Table 2A). Does ced-9 act to inhibit ced-3 function, ced-4 function, or both? To address this issue, we examined whether ced-9 requires ced-4 function to inhibit killing by ced-3 overexpression.

Table 7. ALM killing by ced-3 overexpression can occur in the absence of ced-4 function

\begin{tabular}{lcccc}
\hline & \multicolumn{3}{c}{ Percent surviving ALMs (no. ALMS/no. sides scored) } \\
\cline { 2 - 5 } & wild type & ced-4 & ced-9; ced-3 & ced-4 ced-9; ced-3 \\
\hline $\mathrm{P}_{\text {mec }-7}$ ced-3A & $20(9 / 46)$ & $43(24 / 56)$ & $0(0 / 29)$ & $27(8 / 30)$ \\
$\mathrm{P}_{\text {mec-7 }}$ ced-3B & $42(16 / 38)$ & $30(18 / 6)$ & $0(0 / 37)$ & $38(12 / 32)$ \\
$\mathrm{P}_{\text {mec }-7}$ ced-3C & $100(48 / 48)$ & $90(35 / 39)$ & $21(9 / 43)$ & $85(28 / 33)$ \\
\hline
\end{tabular}

The column headings identify the chromosomal genotypes of the strains examined. The alleles used were ced-9(n2812), ced-3(n717), and ced-4(n1162), except for the line containing the transgene $\mathrm{P}_{m e c-7}$ ced-3A, in which the the ced-3 allele n3002 was used. 
Table 8. Effects of mutations in ced-3 and ced-4 on ced-9 protection against cell death

\begin{tabular}{|c|c|c|c|c|c|c|}
\hline & \multicolumn{6}{|c|}{ Percent surviving ALMs (no. ALMs/no. sides scored) } \\
\hline & ced-3 & ced-9; ced-3 & ced-4 & ced -4 ced -9 & ced-4; ced-3 & ced-4 ced-9; ced-3 \\
\hline \multicolumn{7}{|c|}{$\begin{array}{l}\text { A. ced-9 inhibition of ALM killing by ced-3 } \\
\text { overexpression is facilitated by ced- } 4^{\mathrm{a}}\end{array}$} \\
\hline $\mathrm{P}_{\text {mec }-7}$ ced-3A & $47(16 / 34)$ & $0(0 / 29)$ & $43(34 / 56)$ & $26\{10 / 39\}$ & $48(13 / 27)$ & $27(8 / 30)$ \\
\hline $\mathrm{P}_{m e c-7} c e d-3 \mathrm{~B}$ & $30(8 / 27)$ & $0(0 / 37)$ & $30(18 / 61)$ & $19(9 / 47)$ & $17(5 / 29)$ & $38(12 / 32)$ \\
\hline \multirow[t]{2}{*}{$P_{\text {mec- } 7}$ ced-3C } & $100(34 / 34)$ & $21(9 / 43)$ & $90(35 / 39)$ & $94(73 / 78)$ & $98(40 / 41)$ & $85(28 / 33)$ \\
\hline & ced-4 & ced-4 ced-9 & ced-3 & ced-9; ced-3 & ced-4; ced-3 & ced-4 ced-9; ced-3 \\
\hline \multicolumn{7}{|c|}{ B. Effects of ced- 3 on ced- 9 inhibition of $A L M$ killing by ced- $4^{b}$} \\
\hline $\mathrm{P}_{\text {mec-7 }}$ ced-4A & $43(12 / 28)$ & $0(0 / 30)$ & $71(27 / 38)$ & $69\{69 / 100\}$ & $80(32 / 40)$ & $71(27 / 38)$ \\
\hline $\mathrm{P}_{\text {mec- } 7}$ ced-4B & $94(32 / 34)$ & $53(18 / 34)$ & $100(20 / 20)$ & $97(34 / 35)$ & $98(39 / 40)$ & $84(27 / 32)$ \\
\hline $\mathrm{P}_{\text {mec }-7}$ ced-4C & $97(36 / 37)$ & $42(15 / 36)$ & $100(37 / 37)$ & $98(39 / 40)$ & $97(37 / 38)$ & $98(39 / 40)$ \\
\hline $\mathrm{P}_{\text {mec }-7}$ ced-4D & $100(36 / 36)$ & $15(4 / 27)$ & $100(36 / 36)$ & $100(42 / 42)$ & N.D. & $100(40 / 40)$ \\
\hline
\end{tabular}

${ }^{a}$ The column headings identify the chromosomal genotypes of the strains examined. The alleles used were ced-9(n2812), ced-3(n717), and ced-4(n1162), except for the line containing the transgene $\mathrm{P}_{\text {mec. }}$ ced-3A, in which the ced-3 allele n3002 was used.

${ }^{b}$ The column headings identify the chromosomal genotypes of the strains examined. The alleles used were ced-9(n2812), ced-3(n717), and ced-4(n1162). N.D. Not determined.

Table 8A shows that whereas for $\mathrm{P}_{\text {mec-7 }}$ ced-3-containing ced-4|+| lines, ALMs survive better if ced-9|+| function is present, ALMs in $\mathrm{P}_{\text {mec- } 7}$ ced-3--containing ced-4|-1 lines survive to similar extents in ced-9 $+\mid$ ) and ced-9 mutant backgrounds. For example, in line $\mathrm{P}_{\text {mec- } 7}$ ced-3B, ALMs survived on 5 of the $29(17 \%)$ sides scored in a ced-4; ced-3 background and on 12 of the $32(37 \%)$ sides scored in a ced-4 ced-9; ced-3 background; that is, ced-9 function did not protect against killing by ced-3-overexpression in the absence of ced-4 function. These results suggest that endogenous ced-9 inhibits ced-3 activity in ced-3-overexpression strains by acting at least in part via ced-4.

A similar analysis using $\mathrm{P}_{m e c-7} c e d-4$ transgenes is presented in Table $8 \mathrm{~B}$. However, because killing by a $\mathrm{P}_{\text {mec- }}$. 7ced-4 transgene in a ced-3|-1) background was inefficient, we cannot assess whether ced-3 might be required for protection from ced-4 killing by ced-9.

\section{Overexpression of ced-9 can protect cells killed by overexpression of ced- 4}

Because endogenous ced-9 could protect against cell death induced by ced-4 overexpression, we tested whether overexpression of ced-9 in mec-7-expressing cells would prevent the ectopic cell deaths caused by overexpression of ced-4 in these cells. We examined the effect of a $P_{\text {mec- } 7}$ ced-9 fusion (carried as an extrachromosomal array) on survival of ALMs in line $\mathrm{P}_{\text {mec- } 7}$ ced-4D in a ced -4 ced-9 background. We found that in lines transgenic for both $\mathrm{P}_{\text {mec }-7}$ ced-4 and $\mathrm{P}_{\text {mec- } 7}$ ced-9, more ALMs survived than in the absence of $\mathrm{P}_{\text {mec. }}$ ced-9 or in the presence of a $\mathbf{P}_{\text {mec- }-7} c e d-9$ construct containing a frameshift mutation in the ced-9 gene (see Table 9; Material and methods). These results suggest that overexpression of ced-9 is sufficient to protect mec-7-expressing cells from killing by ced-4 overexpression and demonstrate that ced-9 acts in a cell autonomous fashion to inhibit programmed cell death. We were not able to protect against killing by overexpression of $\mathrm{P}_{\text {mec- } 7}$ ced-3A with a $\mathrm{P}_{\text {mec- } 7}$ ced- 9 transgene to an extent greater than the protection conferred by the presence of endogenous ced-9 (data not shown).

Overexpression of either ced-3 or ced-4 can kill $D D$ neurons

To see whether overexpression of ced-3 or ced-4 could kill cells other than mec-7-expressing cells, we fused a ced-3 or ced-4 cDNA to the promoter for the unc-30 gene, which is expressed in the VD and DD neurons as well as in a few other cells (Jin et al. 1994; Y. Jin, pers. comm.), and obtained lines containing integrated copies of either $\mathrm{P}_{\text {unc-3o }}$ ced-3 or $\mathrm{P}_{\text {unc-3o }}$ ced-4. As Table 10 shows, we observed that $\mathrm{P}_{\text {unc-30 }}$ ced-3 and $\mathrm{P}_{\text {unc-30}}$ ced-4 transgenes could kill DD neurons in ced-9; ced-3 and ced-4 ced-9 backgrounds, respectively.

We obtained one line containing integrated copies of both $\mathrm{P}_{\text {unc-30}}$ ced-3 and $\mathrm{P}_{\text {unc-3o }}$ ced-4 $\left(\mathrm{P}_{\text {unc-3o }}\right.$ ced-3/4A). We observed DDs missing in this line as well in both ced-9; ced-3 and ced-4 ced-9 backgrounds (data not shown). To confirm that these cells were missing because they were dying by programmed cell death, we observed the pattern of cell divisions leading to the formation of 8 of the 13 VD neurons in the ventral cord of a transgenic animal carrying both unc-30 fusion constructs. Figure 1B shows that two of these cells underwent a process morphologically similar to normal programmed cell death.

Table 10 also shows that an endogenous ced-4 mutation inhibited killing by $\mathrm{P}_{\text {unc-30}}$ ced-3 transgenes in ced91-1 animals and that an endogenous ced-3 mutation inhibited killing by $\mathrm{P}_{\text {unc-30 }}$ ced-4 transgenes in ced-9(-) animals. These results parallel our findings with the 
Table 9. Overexpression of ced-9 can protect from killing by overexpression of ced-4

\begin{tabular}{|c|c|}
\hline & $\begin{array}{l}\text { Percent of surviving ALMs } \\
\text { (no. ALMs/no. sides scored) }\end{array}$ \\
\hline & ced -4 ced -9 \\
\hline $\mathrm{P}_{m e c-7} \mathrm{ced}-4 \mathrm{D}$ & $15(4 / 27)$ \\
\hline $\mathrm{P}_{m e c-7}$ ced-4D; $\mathrm{P}_{\text {mec } 7}$ ced-9-1 & $70(14 / 20)$ \\
\hline $\mathrm{P}_{\text {mec-7 }}$ ced-4D; $\mathrm{P}_{\text {mec }-7}$ ced-9-2 & $63(17 / 27)$ \\
\hline $\mathrm{P}_{m e c-7} c e d-4 \mathrm{D}_{;} \mathrm{P}_{\text {mec }-7}$ ced-9-3 & $83(20 / 24)$ \\
\hline $\mathrm{P}_{\text {mec-7 }}$ ced-4D; $\mathrm{P}_{\text {mec }-7}$ ced-9(lf)-1 & $13(3 / 24)$ \\
\hline $\mathrm{P}_{m e c-7} c e d-4 \mathrm{D} ; \mathrm{P}_{\text {mec } \rightarrow}$ ced-9(lf)-2 & $5(1 / 20)$ \\
\hline $\mathrm{P}_{\text {mec }-7}$ ced-4D; $\mathrm{P}_{\text {mec }-7}$ ced-9(lf)-3 & $19(4 / 21)$ \\
\hline
\end{tabular}

Each row indicates an independently derived trangenic line containing the integrated transgene $\mathrm{P}_{\text {mec-7 }}$ ced-4D and (except for row 1 ) an extrachromosomal transgene containing either a wildtype or a mutant ced-9 cDNA. Each extrachromosomal array was established in a ced-4(n1162) ced-9(n2812); nIs45; lin15(n765) background. $\mathrm{P}_{\text {mec-7 }}$ ced-9 arrays contained a wild-type ced-9 cDNA. $P_{\text {mec- } 7}$ ced-9(If) arrays contained a frameshift mutation in an otherwise wild-type ced-9 cDNA. Each array was coinjected with a plasmid containing the lin-15 gene (see Materials and methods).

mec-7 promoter fusion constructs in a ced-9|-| background.

Unlike the mec-7 promoter fusion constructs, none of our unc-30 promoter fusion constructs showed extensive killing of DD neurons in a ced-9| | | background, making it impossible to assess if ced-3 can bypass the requirement for ced-4 in a ced-9|+| animal or if ced-4 can bypass the requirement for ced-3 in a ced-9 $1+\mid$ animal. That ced-3 and ced-4 transgenes failed to kill DD neurons in ced-9 $1+\mid$ animals might be a consequence of insufficient expression from the unc-30 promoter /we never observed complete killing of DD neurons even in a ced -9 mutant background). Alternatively, this difference might reflect a difference between unc-30- and mec-7expressing cells.

\section{Discussion}

To study the roles of ced-3, ced-4, and ced-9 in programmed cell death in $C$. elegans, we developed a method for assaying the effects of overexpressing these cell-death genes as transgenes in cells that are mutationally defective in specific endogenous cell-death activities. Specifically, we expressed cell-death genes as transgenes under the control of two cell type-specific promoters, the $P_{m e c-7}$ promoter, which causes gene expression within a set of mechanosensory neurons, including the ALMs (Savage et al. 1989), and the $\mathrm{P}_{\text {unc-3o }}$ promoter, which causes gene expression in a different set of neurons, including the DDs (Jin et al. 1994). Expression of ced-3 or ced-4 killed both ALMs and DDs, suggesting that if overexpressed either gene is sufficient to activate the cell-death program in cells that normally live.

The system we have developed for assessing the effects on cell death and cell survival of specific transgenes could be used for the analysis of any newly discovered $C$. elegans cell-death genes. Furthermore, because the mechanisms of programmed cell death seem likely to be conserved among organisms as diverse as nematodes, insects, and mammals (e.g., Horvitz et al. 1994), this system also should be useful for the analysis of cell-death genes from other organisms, such as those that encode the human $\mathrm{Bcl}-2$ protein and the baculovirus p35 protein, both of which have been shown to inhibit programmed cell death in C. elegans (Vaux et al. 1992; Hengartner and Horvitz 1994a; Sugimoto et al. 1994; Xue and Horvitz 1995).

We suggest that expression of ced-3 and ced-4 under the control of other promoters could provide a useful method for specific cell ablation. Such a method would complement that of laser microsurgery le.g., Sulston and White 1980; Avery and Horvitz 1987; Bargmann et al. 19931, which has been used extensively to define cell functions and reveal cell interactions in $C$. elegans. Whereas laser microsurgery can be used to kill any cell, relatively few cells and animals can be readily analyzed using this approach. The use of ced-3 or ced-4 transgenes for cell killing would allow many cells at many times of development to be killed and could generate sufficient numbers of animals lacking specific cells for biochemical studies or mutant hunts. A very strong promoter might allow such killing experiments to be performed using a wild-type genetic background. However, in general, an absence of ced-9 function most likely would greatly facilitate killing, which leads us to suggest that most such experiments should be attempted using either a ced-9; ced-3 or a ced-4 ced-9 background.

\section{Killing by overexpression of ced-3 or ced- 4 is similar to normal programmed cell death}

The ectopic cell deaths we observed in lines carrying either $\mathrm{P}_{\text {mec-7 }}$ or $\mathrm{P}_{\text {unc-3o }}$ fusion constructs to ced-3 or ced -4 were similar to programmed cell deaths by a number of criteria. First, ectopically dying cells had the same characteristic refractile appearance when viewed with Nomarski optics as normal programmed cell deaths. Second, the characteristic ultrastructural features of programmed cell death-darkly staining cytoplasm, reduced cytoplasmic volume, and darkly staining nuclear matter-were present in the ectopically dying cells. Third, mutations in a gene required for the engulfment of corpses resulting from normal programmed cell deaths prevented the engulfment of corpses from ectopic cell deaths, suggesting that the ectopic cell deaths resembled normal cell deaths. Fourth, a mutation that prevents the degradation of the DNA of cells that normally die prevented also the degradation of the DNA of ALM cells killed ectopically. Fifth, the extent of killing by ced-3 or ced-4 overexpression was influenced by endogenous mutations in genes known to affect normal programmed cell deaths (ced-3, ced-4, and ced-9|, strongly suggesting that the molecular components responsible for the ectopic cell deaths correspond to those involved in normal programmed cell deaths. 
Table 10. Overexpression of ced-3 or ced-4 can kill DD neurons

\begin{tabular}{lcccc}
\hline & \multicolumn{3}{c}{ Percent of surviving DDs (no. DDs scored/no. expected) } \\
\cline { 2 - 5 } & ced-9; ced-3 & ced-3 & ced-4 ced-9 & \multicolumn{1}{c}{ ced-4 } \\
\hline $\mathrm{P}_{\text {unc-30 }}$ ced-3A & $18(11 / 60)$ & $95(38 / 40)$ & $100(88 / 88)$ & $98(39 / 40)$ \\
$\mathrm{P}_{\text {unc-3o }}$ ced-3B & $18(7 / 40)$ & $98(39 / 40)$ & $100(40 / 40)$ & $98(39 / 40)$ \\
$\mathrm{P}_{\text {unc-30 }}$ ced-4A & $100(40 / 40)$ & $100(40 / 40)$ & $15(6 / 40)$ & $100(40 / 40)$ \\
$\mathrm{P}_{\text {unc-30 }}$ ced-4B & $100(40 / 40)$ & $100(40 / 40)$ & $3(1 / 40)$ & $100(40 / 40)$ \\
\hline
\end{tabular}

Each row indicates an independently derived transgenic line containing a given integrated transgene. Column headings identify the chromosomal genotypes of the strains examined. Fractions indicate the number of DD neurons scored and the number of expected DDs. The alleles used were ced-9(n2812), ced-3(n717), and ced-4(n1162).

ced-3, ced-4, and ced-9 act cell autonomously

All of the ectopic deaths we observed were of cells known to express the promoter we used. No surrounding cells were ever observed to die. These results suggest strongly that killing by overexpression of either ced-3 or ced-4 is cell autonomous. Previously, genetic mosaic analyses demonstrated that wild-type copies of ced-3 and ced- 4 were required in lineages generating cells that normally died to cause the deaths of those cells /Yuan and Horvitz 1990). These experiments, however, did not offer a cellular resolution capable of limiting the requirement for these genes to the dying cell itself. Our results demonstrate that ced-3 and ced-4 can act cell autonomously to cause cell death, strongly supporting the hypothesis that ced-3 and ced-4 normally do so. In addition, we have found that ced-9 can act cell autonomously to prevent cell death, because overexpression of ced-9 in mec-7-expressing cells rescued killing by overexpression of ced-4 in the same cells.

The genetic pathway for programmed cell death in C. elegans

Killing by overexpression of $c e d-3$ did not require endogenous ced-4 function, whereas killing by overexpression of ced-4 was at least in part dependent on endogenous ced-3 function. These results suggest either that ced-4 acts upstream of ced-3 and ced-4 function can be bypassed by high levels of ced-3 activity or that ced-3 and ced-4 act in parallel, with ced-3 perhaps having a greater ability to kill (Fig. 2A). Our finding that ced-4 appears to facilitate the inhibition of ced-3 by ced-9 suggests that ced-9 acts to negatively regulate ced-4; our data do not indicate whether ced-9 also acts to negatively regulate ced-3 (Fig. 2B). It is conceivable that this proposed pathway applies to cells that die in our overexpression system but not to cells that normally die.

Interestingly, in the absence but not in the presence of ced-9 function, ALM killing by overexpression of ced-3 is potentiated by the presence of a functional ced-4 gene. Why might ced-4 function matter only if ced-9 is inactive? One possible explanation based on the hypothesis that ced-9 acts upstream of ced-4 is that the ALMs are cells that normally live and, as such, presumably have active ced-9 function. This ced-9 activity might inhibit any endogenous ced-4 function, so that the presence or absence of a ced-4 $1+1$ allele would be irrelevant. However, if ced- 9 were inactivated by mutation, ced-4 might become functional in the ALMs, thus potentiating killing by a ced-3 transgene.

The behavior of ced-4 in our experiments suggests a similarity between the action of the CED-4 protein and the action of Bcl-2-related proteins that induce apoptosis, such as Bax (Oltvai et al. 1993), Bak (Chittenden et al. 1995; Farrow et al. 1995; Kiefer et al. 1995|, and Bad (Yang et al. 1995). Overexpression of Bax, for example, results in cell death, just as does overexpression of ced-4, and overexpression of $b c l-2$ blocks this death (Oltvai et al. 1993) just as overexpression of ced-9 blocks death caused by overexpression of ced-4. Similar interactions exist with Bak (Kiefer et al. 1995) and Bad (Yang et al. 1995). Although CED-4 and the Bcl-2 family do not have obvious sequence similarity, these proteins might similarly mediate signaling between a negative regulator of cell death (e.g., CED-9/Bcl-2) and a cysteine-protease activator of cell death (e.g., CED-3/ICE-like protease). Alternatively, because both ced-9 and ced-3 have mammalian counterparts that are involved in programmed cell death, it is possible that a protein similar in both structure and function to CED-4 exists in mammals.

ced-3, ced-4, and ced-9 might all normally be expressed in surviving cells

As discussed above, we found that ALM killing by a ced-4 transgene was greatly reduced and possibly eliminated in animals that lack ced-3 function, suggesting that ced-4-induced killing requires ced-3 activity (see Tables 5 and 6 ). Because ced-3 acts cell autonomously, this finding suggests that wild-type ALMs have ced-3 function. Similarly, ALM killing by either a ced-3 or a ced-4 transgene was greater in animals that lacked ced-9 function than in ced-9|+| animals (see Tables $2 A, B$ ), and ced-9 can act cell autonomously. These findings suggest that wild-type ALMs have ced-9 function. Finally, protection by ced-9 against ALM killing by a ced-3 transgene might be mediated by ced-4 function (see Table $8 \mathrm{~A}$ ), and ced-3-induced ALM killing was reduced in animals lacking ced-4 function in the absence of ced-9 activity (see Table 8A). Because ced-4 also acts cell autono- 
mously, these findings suggest that wild-type ALMs might have ced-4 function. In short, our observations are consistent with the hypothesis that surviving ALMs contain not only the protective function of ced-9 but also the killing functions of ced-3 and ced-4. Similar conclusions can be drawn for the DD neurons.

Presumably, the killing functions of ced-3 and ced-4 are inhibited in the ALMs and DDs directly or indirectly by the protective function of ced-9. Because overexpression of either ced-3 or ced-4 in the ALMs can overcome the protective function of ced-9 (see Table 1), we propose that in these neurons, and perhaps more generally in all C. elegans cells, there is an antagonism between functions that activate (e.g., ced-3 and ced-4) and functions that inhibit (e.g., ced-9) programmed cell death. Because ced-3, ced-4, and ced-9 do not seem to affect each other's transcription (S. Shaham and H.R. Horvitz, unpubl.; M. Hengartner, pers. comm.; Yuan and Horvitz 1992; Yuan et al. 1993), it is likely that this antagonism is not at the transcriptional level but rather involves the activities of the proteins encoded by these genes. Cells might initiate programmed cell death either by reducing a protective activity or by increasing a killing activity. Interestingly, not all of our overexpression lines could overcome the protective effects of ced-9 (see Table 1). This observation suggests that the dosage of the ced-3 or the ced-4 product in these lines was insufficient to overcome ced-9 protection. Supporting this notion is our observation that lines heterozygous rather than homozygous for the insertions $\mathrm{P}_{\text {mec- } 7}$ ced-3B, $\mathrm{P}_{\text {mec- } 7}$ ced-3A, and $\mathrm{P}_{\text {mec }-7}$ ced-4A showed little ALM death (S. Shaham and H.R. Horvitz, unpubl.). For example, ALMs survived on 23 of the $25(92 \%)$ sides scored in animals heterozygous for the $\mathrm{P}_{\text {mec- }}$ ced-4A transgene in a wild-type background as opposed to 4 of the $39(10 \%)$ sides in $\mathrm{P}_{\text {mec-7 }}$ ced-4A homozygotes, indicating that gene dosage is important for killing by either ced -3 or ced-4.

Our hypothesis that surviving cells in C. elegans might contain antagonistic protective and killing celldeath functions is consistent with a number of findings from studies of programmed cell death in other organisms. For example, in many cases cells can be induced to undergo programmed cell death in the absence of macromolecular synthesis (for review, see Vaux and Weissman 1993|, suggesting that the protein components needed for cell death are present in living cells. Similarly, many and perhaps all mammalian cells are protected by exogenous growth factors from dying by programmed cell death, which has led Raff (1992) to propose that all cells contain cell-death killing factors. Our findings provide direct evidence that at least some living cells are indeed poised for death in this way.

\section{Materials and methods}

\section{General methods and strains}

We cultured C. elegans as described by Brenner (1974). All strains were grown at $20^{\circ} \mathrm{C}$. The wild-type strain used was $C$. elegans variety Bristol strain N2. Genetic nomenclature follows the standard C. elegans system (Horvitz et al. 1979). The mu- tations used have been described by Ellis and Horvitz (1986), Hedgecock et al. (1983), Hengartner et al. (1992), and Sulston (1976) or were isolated by us. These mutations are as follows: LG I: ced-1(e1735); LG III: ced-4(n1162), ced-9(n2812, n1950, n1950 n2161), unc-69(e587); LG IV: ced-3(n717, n718, n1040, n1129, n2433, n3002), LG X: nuc-1(e1392), lin-15(n765); Allele designations for the integrated lines are as follows: $\mathrm{P}_{\text {mec-7 }} \mathrm{ced}$ $3 \mathrm{~A}$ is nIs50, $\mathrm{P}_{\text {mec }-7}$ ced-3B is nIs 38, $\mathrm{P}_{\text {mec- }-7}$ ced-3C is nIs33, $\mathrm{P}_{\text {mec }}$ 7 ced-4A is nIs31, $\mathrm{P}_{\text {mec }-7}$ ced-4B is nIs 44, $\mathrm{P}_{\text {mec- } 7}$ ced-4C is nIs47, $\mathrm{P}_{\text {mec }-7}$ ced-4D is nIs 45, $\mathrm{P}_{\text {mec }-7}$ ced-3/4A is nIs32, $\mathrm{P}_{\text {mec }-7}$ ced $-3 / 4 \mathrm{~B}$ is nIs29, $\mathrm{P}_{\text {unc-3o }}$ ced-4A is nIs46, and $\mathrm{P}_{\text {unc-30 }}$ ced-4B is nIs 48 . The integrated mec-7-lac $Z$ fusion construct is designated as allele jeIs1 (J. Way, pers. comm.).

\section{Plasmid constructions}

$\mathrm{P}_{\text {mec-7 }}$ ced-3: The vector pPD52.102 (A. Fire, M. Hamelin, and J. Culotti, pers. comm.) was digested with the restriction enzymes NheI and EcoRV and was ligated to an SpeI-SmaI fragment obtained from plasmid pS126, which contains the full-length ced-3 cDNA. $\mathrm{P}_{\text {mec }-7}$ ced-4: The vector pPD52.102 was digested with the restriction enzymes $N h e I$ and $E c o R V$ and was ligated to an SpeI-SmaI fragment obtained from plasmid pS125, which contains a full-length ced-4 cDNA. $\mathrm{P}_{\text {unc-3o }}$ ced-3: Plasmid pS126 was digested with the enzyme SpeI, dephosphorylated using calf intestinal alkaline phosphatase (New England Biolabs, Beverly, $\mathrm{MA}$ ) and ligated to a $3.5-\mathrm{kb} \mathrm{XbaI}$ fragment that contains noncoding sequences upstream of the unc-30 start codon sufficient to express a lacZ reporter gene in the VD and DD neurons of $C$. elegans (Jin et al. 1994; Y. Jin, pers. comm.). Punc.30 ced-4: Plasmid pS125 was digested with the enzyme SpeI as above and ligated to the same $X b a I$ fragment used to construct $\mathrm{P}_{\text {unc-3o }}$ ced3. $\mathrm{P}_{\text {mec-7 }}$ ced-9: The ced-9 cDNA insert of plasmid B30 (Hengartner and Horvitz 1994b) was amplified using the polymerase chain reaction and cloned into the vector pPD52.102 using its NheI and EcoRV sites. $\mathrm{P}_{\text {mec- }}$ ced-9(lf): Plasmid $\mathrm{P}_{\text {mec-7 }}$ ced-9 was digested with $B a m H I$, the overhangs were filled with Klenow enzyme and religated to create a frameshift mutation (Hengartner and Horvitz 1994b). Plasmid pS172 was made as follows: We replaced the sequence TG at the codon encoding cysteine 358 of CED-3 with the sequence GC using an oligonucleotide-mediated site-directed mutagenesis kit and following the instructions of the manufacturer (Amersham, Arlington Heights, IL). An oligonucleotide that encodes the peptide QAARG (5' -CGTTTTTGTGCAGGCTGCTCGAGGCGAACGTCGT$3^{\prime}$ ) was used to introduce the mutation, and plasmid pS126 was used as the template. The sequence of the entire mutated plasmid was determined to confirm that only the desired mutation was introduced. The resulting plasmid was then digested with the enzymes SpeI and SmaI and ligated to the plasmid pPD52.102 as described above to generate plasmid pS172. Plasmid pS178 (which contains a T-to-A substitution at the codon encoding isoleucine 258 of CED-4) was made as above except that an oligonucleotide encoding the peptide TNRWA (5'-GCTCCTGAGCCCAACGATTTGTTTCTTCTTGAACT-3') was used to introduce the mutation, and plasmid pS125 was used as the template.

\section{Germ-line transformation and integration of} extrachromosomal arrays

Our procedure for microinjection and germ-line transformation followed that of Fire (1986) and Mello et al. (1991). DNA for injections was purified using a Qiagen system and following the instructions of the manufacturer (Qiagen Inc., Chatsworth, CA). The concentrations of all plasmids used for injections were 
between 50 and $100 \mu \mathrm{g} / \mathrm{ml}$. All constructs were coinjected with the pRF4 plasmid, which contains the rol-6(su1006) allele as a dominant marker. Animals carrying the pRF4 plasmid exhibit a roller (Rol) phenotype. We transformed strains of genotype ced9(n2812); ced-3(n717), ced-4(n1162) ced-9(n2812), or wild type. Approximately 30 animals were injected in each experiment, and 50-100 Fl Rol animals were picked onto separate plates. F1 animals segregating Rol progeny were established as lines containing extrachromosomal arrays (Way and Chalfie 1988). To assay the activity of $\mathrm{P}_{m e c-7} c e d-9$ and $\mathrm{P}_{m e c-7}$ ced-9(lf), we injected animals of genotype ced-4(n1162) ced-9(n2812); nIs45; lin$15(n 765)$ with each plasmid and with a plasmid containing the wild-type lin-15 gene (Clark et al. 1994; X. Lu, pers. comm.). Approximately $40 \mathrm{~F} 1$ non-Lin- 15 animals were obtained in each experiment, and lines transmitting the non-Lin-15 phenotype were established.

To obtain lines containing integrated copies of the $\mathrm{P}_{m e c-7} c e d$ $3, \mathrm{P}_{\text {mec- } 7}$ ced-4, $\mathrm{P}_{\text {unc- } 30}$ ced- 3 , or $\mathrm{P}_{\text {unc- } 30}$ ced- 4 constructs, we exposed a plate of worms containing a given construct as an extrachromosomal array to $\gamma$ rays or X rays at a dose of 4500 rads. Thirty to 50 fourth larval stage animals (L4s) were picked from the plate onto a separate plate and allowed to generate self progeny. F1 Rol progeny of the mutagenized animals were picked onto individual plates and allowed to generate self progeny. Six to eight Rol F2 animals were picked from each F1 plate and allowed to generate self progeny. F2 plates containing 100\% Rol animals were maintained as integrated lines. The integration event was confirmed by a cross with wild-type animals. Putative heterozygote animals from these crosses were allowed to generate self progeny and were shown to segregate homozygous Rol animals at a frequency of approximately one in three animals picked. These results also showed that all our integrated lines had a dominant Rol phenotype. All integrated strains we obtained were backcrossed at least twice either to N2 or to another strain when appropriate. Overall, we screened $\sim 30,000$ F2 animals to obtain three independent $P_{\text {mec-7 }}$ ced-3 integrants, 30,000 F2 animals to obtain four independent $P_{\text {mec- } 7}$ ced-4 integrants, 10,000 F2 animals to obtain two independent $P_{\text {unc-3o }}$ ced-3 integrants, $10,000 \mathrm{~F} 2$ animals to obtain two independent $\mathrm{P}_{\text {unc-3o }}$ ced-4 integrants, $5000 \mathrm{~F} 2$ animals to obtain two independent integrants containing both the $\mathrm{P}_{\text {mec- } 7}$ ced-3 and $\mathrm{P}_{\text {mec-7 }}$ ced-4 constructs, and $1000 \mathrm{~F} 2$ animals to obtain one integrant containing both $\mathrm{P}_{\text {unc-30 }}$ ced-3 and $\mathrm{P}_{\text {unc-30 }}$ ced-4 constructs. None of the integrated lines used in our experiments exhibited any obvious abnormality besides the Rol, $\mathrm{Mec}$, or Unc-30 phenotypes.

\section{Assays for ALM and DD cell death}

ALM cell death was assayed by scoring transgenic animals for the presence of ALM nuclei as follows: approximately 40 early L1 animals were mounted onto a drop of $50 \mathrm{mM} \mathrm{NaN}_{3}$ in M9 buffer (Sulston and Hodgkin 1988) on a slide containing a pad of $5 \%$ agar in water and were covered with a coverslip. Animals were then observed using Nomarski optics (Sulston and Horvitz 1977). The Rol phenotype conferred by the pRF4 plasmid is not expressed in Ll larvae, which thus are easier to score for the presence or absence of the ALMs. The left side of animals was scored for the presence of an ALML nucleus, and the right side of the animals was scored for the presence of the ALMR nucleus. After scoring L1s for the presence or absence of ALMs, we allowed them to mature; only Rol animals or animals segregating Rol progeny were included in our data.

DD cell death was assayed as follows; Young Ll animals (at a stage prior to the migration of the P-cell nuclei) from an integrated line were scored using Nomarski optics for the presence of 15 neuronal nuclei located between the retrovesicular ganglion and the pre-anal ganglion. Four of these 15 nuclei are DD nuclei (Sulston and Horvitz 1977), some of which were missing in strains containing $\mathrm{P}_{\text {unc-30}}$ ced-3 or $\mathrm{P}_{\text {unc-30 }}$ ced-4 constructs.

We also directly observed the deaths of PVM neurons in ced9(n2812); ced-3(n717) $\mathrm{P}_{\text {mec-7 }}$ ced-3/4A and in ced-4(n1162) ced9(n2812); $\mathrm{P}_{\text {mec }-7}$ ced-4A animals by following the QL cell lineage (Sulston and Horvitz 1977) in living larvae $(n=12)$. Occasionally, we also saw the sister of the PVM neuron, SDQL, undergo programmed cell death. The mec-7 promoter is known to be expressed weakly in this cell (M. Chalfie, pers. comm.), supporting our hypothesis that the level of overexpression of ced-3 or ced-4 is important for the penetrance of cell killing. We also observed directly the deaths of the VD neurons in one ced9(n2812); ced-3(n717); $\mathrm{P}_{\text {unc-3o }}$ ced-3/4A animal by following the P5-P12 cell lineages in that animal.

\section{Acknowledgments}

S.S. would like to dedicate this paper to the memory of his father, Prof. Jacob Shaham. We thank Ewa Davison, Michael Koelle, Mark Metzstein, Beth Sawin, and Gillian Stanfield for helpful comments about the manuscript, Erika Hartwieg for help with the electron microscopy, Yishi Jin for sharing unpublished results and Jeff Way for the allele ieIs1. S.S. was supported by a William Keck Foundation fellowship and a fellowship from the Glaxo Research Institute. H.R.H. is an Investigator of the Howard Hughes Medical Institute.

The publication costs of this article were defrayed in part by payment of page charges. This article must therefore be hereby marked "advertisement" in accordance with 18 USC section 1734 solely to indicate this fact.

\section{References}

Arends, M.J. and A.H. Wyllie. 1991. Apoptosis: Mechanisms and roles in pathology. Int. Rev. Exp. Path. 32: 223-254.

Avery, L. and H.R. Horvitz. 1989. A cell that dies during wildtype C. elegans development can function as a neuron in a ced-3 mutant. Cell 51: 1071-1078.

Bargmann, C.I., E. Hartwieg, and H.R. Horvitz. 1993. Odorantselective genes and neurons mediate olfaction in C. elegans. Cell 74: 515-527.

Barres, B.A., R. Schmid, M. Sendnter, and M.C. Raff. 1993. Multiple extracellular signals are required for long-term oligodendrocyte survival. Development 118: 283-295.

Brenner, S. 1974. The genetics of Caenorhabditis elegans. Genetics 77: 71-94.

Cerretti, D.P., C.J. Kozlosky, B. Mosley, N. Nelson, K.V. Ness, T.A. Greenstreet, C.J. March, S.R. Kronheim, T. Druck, L.A. Cannizzaro, K. Huebner, and R.A. Black. 1992. Molecular cloning of the interleukin- $1 \beta$ converting enzyme. Science 256: 97-100.

Chalfie, M. 1993. Touch receptor development and function in Caenorhabditis elegans. I. Neurobiol. 24: 1433-1441.

Chittenden, T., E.A. Harrington, R. O'Connor, C. Flemington, R.J. Lutz, G.I. Evan, and B.C. Guild. 1995. Induction of apoptosis by the Bcl-2 homologue Bak. Nature 374: 733-736.

Clark, S.G., X. Lu, and H.R. Horvitz. 1994. The Caenorhabditis elegans locus lin-15, a negative regulator of a tyrosine kinase signaling pathway, encodes two different proteins. Genetics 137: 987-997.

Cohen, J.J. and R.C. Duke. 1984. Glucocorticoid activation of a calcium-dependent endonuclease in thymocyte nuclei leads to cell death. J. Immunol. 32: 38-42. 
Ellis, H.M. and H.R. Horvitz. 1986. Genetic control of programmed cell death in the nematode C. elegans. Cell 44: 817-829.

Ellis, R.E. and H.R. Horvitz. 1991. Two C. elegans genes control the programmed cell deaths of specific cells in the pharynx. Development 112: 591-603.

Ellis, R.E., J. Yuan, and H.R. Horvitz. 1991a. Mechanisms and functions of cell death. Annu. Rev. Cell Biol. 7: 663-698.

Ellis, R.E., D. Jacobson, and H.R. Horvitz. 1991b. Genes required for the engulfment of cell corpses during programmed cell death in Caenorhabditis elegans. Genetics 129: 79-94.

Farrow, S.N., J.H. White, I. Martinou, T. Raven, K.T. Pun, C.J. Grinham, J.C. Martinou, and R. Brown. 1995. Cloning of a bcl-2 homologue by interaction with adenovinus E1B 19K. Nature 374: 731-733.

Fernandes-Alnemri, T., G. Litwack, and E.S. Alnemri. 1994. CPP32, a novel human apoptotic protein with homology to Caenorhabditis elegans cell death protein Ced-3 and mammalian interleukin-l beta-converting enzyme. J. Biol. Chem. 269: 30761-30764.

Fire, A. 1986. Integrative transformation of Caenorhabditis elegans. EMBO I. 5: 2673-2680.

Gagliardini, V., P. Fernandez, R.K.K. Lee, H.C.A. Drexler, R.J. Rotello, M.C. Fishman, and J. Yuan. 1994. Prevention of vertebrate neuronal death by the $\mathrm{crm} A$ gene. Science 263: 826828.

Garcia, I., I. Martinou, Y. Tsujimoto, and J.C. Martinou. 1992. Prevention of programmed cell death of sympathetic neurons by the bcl-2 proto-oncogene, Science 258: 302-304.

Glücksmann, A. 1950. Cell deaths in normal vertebrate ontogeny. Biol. Rev. Cambridge Philos. Soc. 26: 59-86.

Hedgecock, E., J.E. Sulston, and N. Thomson. 1983. Mutations affecting programmed cell deaths in the nematode Caenorhabditis elegans. Science 220: 1277-1280.

Hengartner, M.O., R.E. Ellis, and H.R. Horvitz. 1992. Caenorhabditis elegans gene ced-9 protects cells from programmed cell death. Nature 356: 494-499.

Hengartner, M.O. and H.R. Horvitz. 1994a. C. elegans cell survival gene ced-9 encodes a functional homolog of the mammalian proto-oncogene bcl-2. Cell 76: 665-676.

1994b. Activation of C. elegans cell death protein CED-9 by an amino-acid substitution in a domain conserved in Bcl-2. Nature 369: 318-320.

Hevelone, J. and P.S. Hartman. 1988. An endonuclease from Caenorhabditis elegans: Partial purification and characterization. Biochem. Genet. 26: 447-461.

Hockenbery, D.M., M. Zutter, W. Hickey, M. Nahm, and S.J. Korsmeyer. 1991. BCL2 protein is topographically restricted in tissues characterized by apoptotic cell death. Proc. Natl. Acad. Sci. 88: 6961-6965.

Horvitz, H.R., S. Brenner, J. Hodgkin, and R.K. Herman. 1979. A uniform genetic nomenclature for the nematode Caenorhabditis elegans. Mol. \& Gen. Genet. 175: 129-133.

Horvitz, H.R., S. Shaham, and M.O. Hengartner. 1994. The genetics of programmed cell death in the nematode Caenorhabditis elegans. Cold Spring Harbor Symp. Quant. Biol. 59: 377-385.

Jin, Y., R. Hoskins, and H.R. Horvitz. 1994. Control of type-D GABAergic neuron differentiation by $C$. elegans UNC-30 homeodomain protein. Nature 372: 780-783.

Kiefer, M.C., M.J. Brauer, V.C. Powers, J.J. Wu, S.R. Umansky, L.D. Tomei, and P.J. Barr. 1995. Modulation of apoptosis by the widely distributed Bcl-2 homologue Bak. Nature 374: 736-739.

Kimble, J. and D. Hirsh. 1979. The postembryonic cell lineages of the hermaphrodite and male gonads in Caenorhabditis elegans. Dev. Bio. 70: 396-417.

Kuida, K., J.A. Lippke, G. Ku, M.W. Harding, D.J. Livingston, M.S. Su, and R.A. Flavell. 1995. Altered cytokine export and apoptosis in mice deficient in interleukin-l beta converting enzyme. Science 267: 2000-2003.

Kumar, S., M. Kinoshita, M. Noda, N.G. Copeland, and N.A. Jenkins. 1994. Induction of apoptosis by the mouse Nedd-2 gene, which encodes a protein similar to the product of the Caenorhabditis elegans cell death gene ced-3 and the mammalian IL-1 $\beta$-converting enzyme. Genes \& Dev. 8: 16131626.

Martin, D.P., R.E. Schmidt, P.S. Distefano, O.H. Lowry, J.G. Carter, and E.M. Johnson Jr. 1988. Inhibitors of protein synthesis and RNA synthesis prevent neuronal death caused by nerve growth factor deprivation. $\%$. Cell Biol. 106: 829-844.

Mello, C.C., J.M. Kramer, D. Stinchcomb, and V. Ambros. 1991. Efficient gene transfer in C. elegans: Extrachromosomal maintenance and integration of transforming sequences. EMBO /. 10: 3959-3970.

Miura, M., H. Zhu, R. Rotello, E.A. Hartwieg, and J. Yuan. 1993. Induction of apoptosis in fibroblasts by IL-1 beta-converting enzyme, a mammalian homolog of the $\mathrm{C}$. elegans cell death gene ced-3. Cell 75: 653-660.

Nunez, G., L. London, D. Hockenbery, M. Alexander, J.P. McKearn, and S.J. Korsmeyer. 1990. Deregulated Bcl-2 gene expression selectively prolongs survival of growth factor-deprived hematopoietic cells lines. I. Immun. 144: 3602-3610.

Oltvai, Z.N., C.L. Milliman, and S.J. Korsmeyer. 1993. Bcl-2 heterodimerizes in vivo with a conserved homolog, Bax, that accelerates programmed cell death. Cell 74: 609-619.

Raff, M.C. 1992. Social controls on cell survival and death: An extreme view. Nature 356: 397-400.

Ray, C.A., R.A. Black, S.R. Kronheim, T.A. Greenstreet, P.R. Sleath, G.S. Salvesen, and D.J. Pickup. 1992. Viral inhibition of inflammation: Cowpox virus encodes an inhibitor of the interleukin-1 $\beta$ converting enzyme. Cell 69: 597-604.

Robertson, A.M.G. and J.N. Thomson. 1982. Morphology of programmed cell death in the ventral nerve cord of Caenorhabditis elegans larvae. J. Embryol. Exp. Morph. 67: 89-100.

Savage, C., M. Hamelin, J.G. Culloti, A. Coulson, D.G. Albertson, and M. Chalfie. 1989. mec-7 is a beta tubulin gene required for the production of 15 protofilament microtubules in Caenorhabditis elegans. Genes \& Dev. 3: 870-881.

Sentman, C.L., J.R. Shutter, D. Hockenbery, O. Kanagawa, and S.J. Korsmeyer. 1992. Bcl-2 inhibits multiple forms of apoptosis but not negative selection in thymocytes. Cell 67: 879888.

Stanisic, T., R. Sadlowski, C. Lee, and J.T. Grayhack. 1978. Partial inhibition of castration induced ventral prostate regression with actinomycin D and cyclohexamide. Invest. Urol. 16: 19-22.

Strasser, A., A.W. Harris, and S. Cory. 1992. bcl-2 transgene inhibits $\mathrm{T}$ cell death and perturbs thymic self-censorship. Cell 67: 889-899.

Sugimoto, A., P.D. Friesen, and J.H. Rothman. 1994. Baculovirus p35 prevents developmentally programmed cell death and rescues a ced-9 mutant in the nematode Caenorhabditis elegans. EMBO I. 13: 2023-2028.

Sulston, J.E. 1976. The ventral cord of Caenorhabditis elegans. Phil. Trans. R. Soc. Lond. B 275: 287.

Sulston, J.E. and H.R. Horvitz. 1977. Post-embryonic cell lineages of the nematode Caenorhabditis elegans. Dev. Biol. 82: $110-156$.

Sulston, J.E. and J.G. White. 1980. Regulation and cell auton- 
omy during postembryonic development of Caenorhabditis elegans. Dev. Biol. 78: 577-597.

Sulston, J. and J. Hodgkin. 1988. Methods. In The nematode Caenorhabditis elegans (ed. W.B. Wood and the community of C. elegans researchers), pp. 491-584. Cold Spring Harbor Laboratory Press, Cold Spring Harbor, New York.

Sulston, J.E., E. Schierenberg, J.G. White, and N. Thomson. 1983. The embryonic cell lineage of the nematode Caenorhabditis elegans. Dev. Biol. 100: 64-119.

Thornberry, N.A., H.G. Bull, J.R. Calaycay, K.T. Chapman, A.D. Howard, M.J. Kostura, D.K. Miller, S.M. Molineaux, J.R. Weidner, J. Aunins, K.O. Elliston, J.M. Ayala, F.J. Casano, J. Chin, J.F. Ding, L.A. Egger, E.P. Gaffney, G. Limjuco, O.C. Palyha, S.M. Raju, A.M. Rolando, J.P. Salley, T. Yamin, T.D. Lee, J.E. Shively, M.M. MacCross, R.A. Mumford, J.A. Schmidt, and M.J. Tocci. 1992. A novel heterodimeric cysteine protease is required for interleukin-1 $\beta$ processing in monocytes. Nature 356: 768-774.

Vaux, D.L. 1993. Toward an understanding of the molecular mechanisms of physiological cell death. Proc. Natl. Acad. Sci. 90: 786-789.

Vaux, D.L. and I.L. Weissman. 1993. Neither macromolecular synthesis nor myc is required for cell death via the mechanism that can be controlled by Bcl-2. Mol. Cell. Biol. 13: 7000-7005.

Vaux, D.L., S. Cory, and J.M. Adams. 1988. Bcl-2 gene promotes haemopoietic cell survival and cooperates with c-myc to immortalize pre-B cells. Nature 335: 440-442.

Vaux, D.L., I.L. Weissman, and S.K. Kim. 1992. Prevention of programmed cell death in Caenorhabditis elegans by human bcl-2. Science 258: 1955-1957.

Wang, L., M. Miura, L. Bergeron, H. Zhu, and J. Yuan. 1994. Ich-1, an Ice/ced-3-related gene, encodes both positive and negative regulators of programmed cell death. Cell 78: 739750.

Way, J.C. and M. Chalfie. 1988. mec-3, a homeobox-containing gene that specifies differentiation of the touch receptor neurons in C. elegans. Cell 54: 5-16.

Williams, G.T. and C.A. Smith. 1993. Molecular regulation of apoptosis: Genetic controls on cell death. Cell 74: 777-779.

Xue, D. and H.R. Horvitz. 1995. Inhibition of the Caenorhab ditis elegans cell-death protease CED-3 by a CED-3 cleavage site in baculovirus p35 protein. Nature 377: 248-251.

Yang, E., J. Zha, J. Jockel, L.H. Boise, C.B. Thompson, and S.J. Korsmeyer. 1995. Bad, a heterodimeric partner for Bcl-XL and Bcl-2, displaces Bax and promotes cell death. Cell 80: $285-291$.

Yuan, J. and H. R. Horvitz. 1990. Genetic mosaic analyses of ced-3 and ced-4, two genes that control programmed cell death in the nematode C. elegans. Dev. Biol. 138: 33-41.

- 1992. The Caenorhabditis elegans cell death gene ced-4 encodes a novel protein and is expressed during the period of extensive programmed cell death. Development 116: 309320.

Yuan, J., S. Shaham, S. Ledoux, H.M. Ellis, and H.R. Horvitz. 1993. The C. elegans cell death gene $c e d-3$ encodes a protein similar to mammalian interleukin- $1 \beta$-converting enzyme. Cell 75: 641-652. 


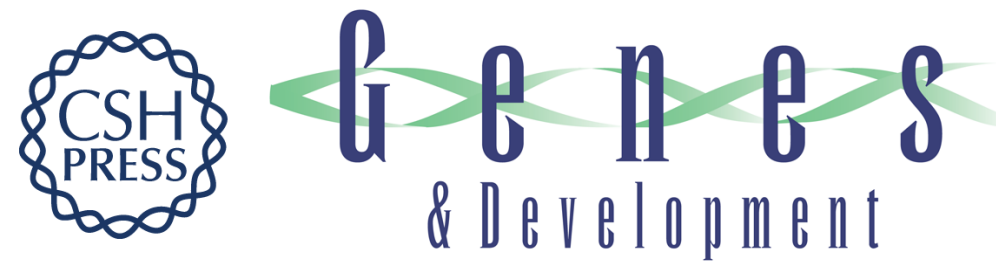

\section{Developing Caenorhabditis elegans neurons may contain both cell-death protective and killer activities.}

S Shaham and H R Horvitz

Genes Dev. 1996, 10:

Access the most recent version at doi:10.1101/gad.10.5.578

References This article cites 63 articles, 21 of which can be accessed free at: http://genesdev.cshlp.org/content/10/5/578.full.html\#ref-list-1

License

Email Alerting

Service

Receive free email alerts when new articles cite this article - sign up in the box at the top right corner of the article or click here.

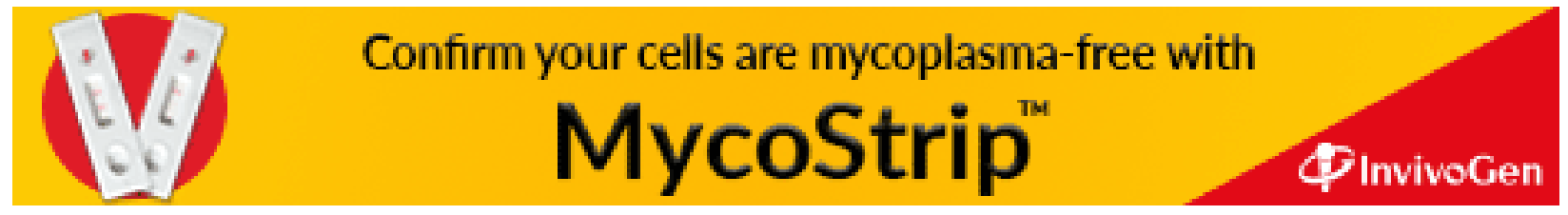

